\title{
ON THE DETERMINATION OF THE TETHER LENGTH FOR AN EXPERIMENTAL ELECTRODYNAMIC SYSTEM
}

\author{
Institute of Technical Mechanics \\ of the National Academy of Sciences of Ukraine and the State Space Agency of Ukraine \\ 15 Leshko-Popel St., Dnipro 49005, Ukraine; e-mail: cvetochekam@rambler.ru
}

The aim of this paper is to analyze the dependence of the tether length of a small experimental electrodynamic space tether system (EDSTS) without additional contactors required for the EDSTS operation in the anodecathode mode on the tether and end body parameters and the orbital parameters. It is shown that for each case of EDSTS motion there exists a critical tether length such that for shorter lengths one should not expect any steadystate mode of interaction with the plasma which would provide a practically measurable current. For an EDSTS to operate in the anode-cathode mode, its length must be greater than the critical one.

The results of this study may be used in choosing the tether parameters for a specific experiment, i. e. an experiment with given end bodies, orbital parameters, and measuring systems.

Keywords small electrodynamic space tether system, spacecraft deorbiting system, geometrical parameters, critical length.

1. Sanmartin J. R., Estes R. D. Cylindrical Langmuir probes beyond the orbital-motion-limited regime. Journal of Physics of Plasmas. 2000. V. 7, No. 10. Pp. 4320-4325.

2. Boyd R. Langmuir probes on spacecraft (in Russian). Plasma Diagnostics. Moscow: Mir. 1971. Pp. 506-538.

3. Kozlov O. V. Electric Probe in Plasma (in Russian). Moscow: Atomizdat, 1969. 290 pp.

4. Sanmartin J. R., Lorenzini E. C. Spherical Collectors Versus Bare Tethers for Drag, Thrust, and Power Generation. 41st AIAA/ASME/SAE/ASEE Joint Propulsion Conference \& Exhibit, 10 - 13 July 2005, Tucson, Arizona. Pp. 1-7.

5. Sanmartin J. R., Lorenzini E. C, Martinez-Sanchez M. Electrodynamic Tether Applications and Constraints. Journal of Spacecraft and Rockets. 2010. V. 47, No. 3. Pp. 142-156.

6. International Reference Ionosphere - IRI-2012 // SPDF Goddard Space Flight Center. URL: https://omniweb.gsfc.nasa.gov/vitmo/iri2012_vitmo.html 